\title{
Learning Factory: is it a Panacea for all Difficulties in Engineering Education?
}

\author{
Sangarappillai Sivaloganathan* and Khalifa Harib \\ Department of Mechanical Engineering, United Arab Emirates University, United Arab Emirates
}

Submission: May 14, 2018; Published: June 13, 2018

*Corresponding author: Sangarappillai Sivaloganathan, Department of Mechanical Engineering, United Arab Emirates University, Po Box 15551, AlAin, United Arab Emirates, Email: Sangarappillai@uaeu.ac.ae

\begin{abstract}
This mini review addresses the question 'how deep subject knowledge and critical thinking skills can be built in engineering graduates so that they will be work-ready at graduation?'. In the developed nations, Learning Factory is increasingly accepted as the means to instil this skill set. The morphology of the Learning Factory permits sufficient flexibility to accommodate different requirements and future developments. The paper argues that the developing nations however have to acquire this technology for progress and to be efficient they have to build the science and technology base at the same time. It concludes that Learning Laboratory can be a panacea for developed nations but it can only be a panacea for developing nations that simultaneously build and reinforce their science and technology bases.
\end{abstract}

Keywords: Learning factory; Educating work-ready graduates; Learning factory for Developing Nations

\section{Introduction}

Deep subject knowledge and critical thinking skills are fundamental to meet the demands of modern knowledge intensive industry and the universities face the challenge to equip engineering graduates with these abilities to make them 'work-ready'. Critical thinking is the intellectually disciplined process of conceptualizing, applying, analysing, synthesizing, and evaluating information gathered from observation, experience, reflection, reasoning, or communication, as a guide to belief and action [1]. 'Learning Factory' is the latest mechanism developed by educators to convert students coming from the high school with no industrial exposure into 'work-ready' graduates. This happens in a time where multi-faceted advancements in science and technology are very rapid and the demand for their application is huge so that the period in the time-line is widely recognized as the fourth industrial revolution, Industry 4. Industry 4.0 is the digital transformation of industrial markets with smart manufacturing. The concept of 'Learning Factory' was conceived in USA and later championed by German Universities. In this mini-review we look at the developments of the 'Learning Factory' in a developed nation where the technology transfer takes the form Research $\rightarrow$ Development $\rightarrow$ Design $\rightarrow$ Production [2]. Looking at the developments we then ponder how this can be adopted by a developing nation where Production $\rightarrow$ Design $\rightarrow$ Development $\rightarrow$ Research is the form of technology transfer.

\section{A Summary Review of the Learning Factory}

Learning Factory is defined as an idealized replica of sections of the value chain in industry where informal, non-formal and formal learning take place [3]. It is a learning environment where processes and technologies are based on a real industrial site, linking production technologies with information and communication technologies. The 'Learning Factory' concept was developed in 1994 by a consortium led by Penn State University to obtain a grant from National science Foundation, NSF, of the USA [4]. A college-wide infrastructure and a 2000 square meters facility equipped with machines, materials and tools was established and utilized to support hundreds of industry-sponsored design projects. European Initiative started in 2011at the '1st Conference on Learning Factories' in Darmstadt. In 2014, a CIRP Collaborative Working Group on learning factories was initiated in order to establish a joint understanding of relevant terms. Various existing definitions were collected and considered and they came up with a two-part definition in the following way:

First, a Learning Factory in a narrow sense is a learning environment specified by

- Processes that are authentic, include multiple stations, and comprise technical as well as organizational aspects

- A setting that is changeable and resembles a real value chain 
- A physical product being manufactured and

- A didactical concept that comprises formal, informal and non-formal learning, enabled by own actions of the trainees in an on-site learning approach.

It provides a real value chain for a physical product in which participants canperform, evaluate, and reflect their own actions in an on-site learning approach.

Second, the learning factory in the broader sense modifies this concept in at least one of the following directions:

- Virtual representations of value added chains.

- The connection of the trainees to the learning processes based on remote ICT connections.

- $\quad$ The product of the learning factory is a service.

Several learning factories have been built in the past. They are physical implementations of feature instances of a generic model of the learning factory. Morphological Analysis is the inclusion of all relevant features, characteristics and their potential attributes of a learning factory in the form of a chart. It gives a picture of both holistic and generic learning factories. It allows simplified illustrations of the correlations between all existing options to conceptualize a learning factory and the specific design of the actual learning factory. From such a chart, a model suiting individual requirements can be specifically established. Sociotechnological megatrends and continued findings from research make the learning factory a journey than a destination and the morphological analysis helps to follow the trends easily. Tisch et al. [5] analyse the morphology of learning factory in the following seven dimensions:

i. Operating model: Nature of operating institution (academic, industrial, etc.); teaching staff, funding.

ii. Purpose and Targets: Strategic orientation of Learning Factory, Purposes, target groups, group constellation, targeted industries, subject matters.

iii. Process: Addressed phases, involved functions, material flow, process type, manufacturing methods \& technologies, etc.

iv. Setting: Learning environment (physical, virtual), work system levels, IT-integration, changeability of setting.

v. Product: Number of different products, variants, type and form of product, product origin, further product use, etc.

vi. Didactics: Learning targets, type of learning environment (green field, brown field), role of trainer, evaluation, etc.

vii. Learning Factory Metrics: Quantitative figures like floor space, FTE, Number of participants per training, etc.

The students in the developed nations while are coming from high school with limited exposure to industry they are a generation that grew up immersed in computers, smart phones, and the Internet. Also the IT, technology and applications are the sole ingredients for a modern factory and they are developed at home for them. The growing acceptance and enthusiasm for learning factory among the developed nations is an indication of its effectiveness there. What about the developing nations.

\section{Technology Transfer from a Developing Nation's Point of View}

Technology is the information necessary to achieve a certain production outcome from a particular means of combining or processing selected inputs which include production processes, intra-firm organizational structures, management techniques, and means of finance, marketing methods or any of its combination [2]. Technology transfer is an acquisition, development and utilization, of technological knowledge by a country other than in which this knowledge originated. Unlike the developed nations the developing nations acquire technology from a developed nation. Bennet \& Vaidya [6] identify the capabilities that can be accrued from technology transfer as skill sets required for:

\section{a. Processing where learning by doing play an important role}

b. Establishing new production facilities or modernisation of existing ones

c. Continuous and incremental upgrading of product design and process technology and

d. Innovating product and process innovation creating new technology in some manufacturing industries.

They argue that the existing knowledge base is important for developing further knowledge and capabilities and new products and processes. They further continue that South Korea moved into advanced technologies by building and reinforcing their scientific and technological base in the 1980s.

\section{Discussion and Conclusion}

The preceding reviews highlight two important points:

i. Learning Factory is an approach, which is proving to have several advantages in the development of competent graduates. Its morphology suggests that it is flexible in several dimensions and therefore can accommodate advancements resulting from the fourth industrial revolution. Learning Factory therefore is a good mechanism for developing countries that desire to industrialize quicker.

ii. Analysis of technology transfer on the other hand suggests that building and reinforcing scientific and technological base is fundamental for the success of the Learning Factories adopted by the developing countries.

Considering the above two observations it is safer to conclude that developing countries that want to use learning factories as 
the mechanism to industrialise faster should (i) identify the technologies that have to be incorporated in the factory (say CNC manufacture for example) when considering the morphology of the Learning factory and (ii) invest on reinforcing and building the supporting technologies in IT and Mechatronics and Control simultaneously. In addition the universities can update relevant educational objectives and educational programs to support and back the use of the Learning Factories.

In conclusion Learning factory can be a panacea for developed nations but it will be a panacea for the developing nations only if they simultaneously build and reinforce their science and technology bases.

\section{References}

1. (2018) Defining Critical Thinking, The Foundation for Critical Thinking.
2. Ramanathan K (2018) (Head of Asian andPacific Centre for Transfer of Technology, APCTT), An Overview of Technology Transfer and Technology Transfer Models.

3. Baenaa F, Guarina A, Moraa J, SauzabJ, Retatc S (2017) Learning Factory: The Path to Industry 4.0, 7th Conference on Learning Factories, CLF 2017, Procedia Manufacturing 9: 73-80.

4. Abelea E, Metternicha J, Michael Tischa M, Chryssolourisb G, Sihnc W, et al. (2015) Learning Factories for research, education, and training, The $5^{\text {th }}$ Conference on Learning Factories 2015, Procedia CIRP 32: 1-6.

5. Tisch M, Ranz F, Abele E, Metternıch J, Vera H (2015) Learning Factory Morphology-Study Of Form And Structure Of An Innovative Learning Approach In The Manufacturing Domain. TOJET: The Turkish Online Journal of Educational Technology-July 2015, Special Issue 2 for INTE 2015.

6. Bennet D, Vaidya K (2001) Meeting Technology Needs of Enterprises for National Competitiveness. Selected Discussion Papers presented at the Vienna Global Forum on Management of Technology, United Nations Development Organization, UNIDO, Austria.

\section{Your next submission with Juniper Publishers will reach you the below assets}

- Quality Editorial service

- Swift Peer Review

- Reprints availability

- E-prints Service

- Manuscript Podcast for convenient understanding

- Global attainment for your research

- Manuscript accessibility in different formats

( Pdf, E-pub, Full Text, Audio)

- Unceasing customer service

Track the below URL for one-step submission https://juniperpublishers.com/online-submission.php 